\title{
Kinetic intermediates in amyloid assembly
}

Chen Liang

Rong Ni

Jillian E. Smith-Carpenter

Fairfield University, jsmith-carpenter@fairfield.edu

W. Seth Childers

Anil K. Mehta

See next page for additional authors

Follow this and additional works at: https://digitalcommons.fairfield.edu/chemistry-facultypubs Copyright 2014 American Chemical Society. Post-print has been archived here. Final published version available http://pubs.acs.org/doi/abs/10.1021/ja508621b

\section{Repository Citation}

Liang, Chen; Ni, Rong; Smith-Carpenter, Jillian E.; Childers, W. Seth; Mehta, Anil K.; and Lynn, David G., "Kinetic intermediates in amyloid assembly" (2014). Chemistry \& Biochemistry Faculty Publications. 23. https://digitalcommons.fairfield.edu/chemistry-facultypubs/23

\section{Published Citation}

Liang, C. $\ddagger$, Ni, R. ¥, Smith, J. E. $\ddagger$, Childers, W. S., Mehta, A. K., Lynn, D. G. Kinetic intermediates in amyloid assembly. Journal of the American Chemical Society 136, no. 43 (October 2014): 15146-15149. 10.1021/ja508621b

This item has been accepted for inclusion in DigitalCommons@Fairfield by an authorized administrator of DigitalCommons@Fairfield. It is brought to you by DigitalCommons@Fairfield with permission from the rightsholder(s) and is protected by copyright and/or related rights. You are free to use this item in any way that is permitted by the copyright and related rights legislation that applies to your use. For other uses, you need to obtain permission from the rights-holder(s) directly, unless additional rights are indicated by a Creative Commons license in the record and/or on the work itself. For more information, please contact digitalcommons@fairfield.edu. 


\section{Authors}

Chen Liang, Rong Ni, Jillian E. Smith-Carpenter, W. Seth Childers, Anil K. Mehta, and David G. Lynn 


\title{
Kinetic Intermediates in Amyloid Assembly
}

\author{
Chen Liang $\ddagger$, Rong Nit, Jillian E. Smith $\ddagger$, W. Seth Childers $\dagger$, Anil K. Mehta*, and David G. Lynn* \\ Departments of Chemistry and Biology, Emory University, Atlanta, GA 30322 (USA)
}

\begin{abstract}
In contrast to an expected Ostwald-like ripening of amyloid assemblies, the nucleating core of the Dutch mutant of the $A \beta$ peptide of Alzheimer's disease assembles through a series of conformational transitions. Structural characterization of the intermediate assemblies by isotope-edited IR and solid-state NMR reveal unexpected strand orientation intermediates and suggest new nucleation mechanisms in a progressive assembly pathway.
\end{abstract}

The self-assembly of proteins into amyloid is an initiating step in misfolding ${ }^{1,2}$ and infectious prion ${ }^{3}$ diseases. The process is traditionally described as a thermodynamically-driven "ripening" of accessible conformations and the range of phases that exist under a given set of conditions is the result of amyloid polymorphism. Recently, secondary nucleation sites ${ }^{4,5}$ have suggested the possibility of a more progressive pathway contributing to different assembled phases. Here we experimentally demonstrate the minimal nucleating core ${ }^{6,7}$ of the Dutch mutant ${ }^{8}$ of the $A \beta$ peptide of Alzheimer's disease (AD), $A \beta(16-22) E 22 Q$ or $A c^{-16} K L V F F A 22 Q-N_{2}$, assembles as anti-parallel $\beta$-strands that later transition completely into parallel arrays. These studies define a progressive pathway for amyloid assembly, even for simple model peptides, and reveal new mechanisms for achieving polymorphic diversity in disease etiology.
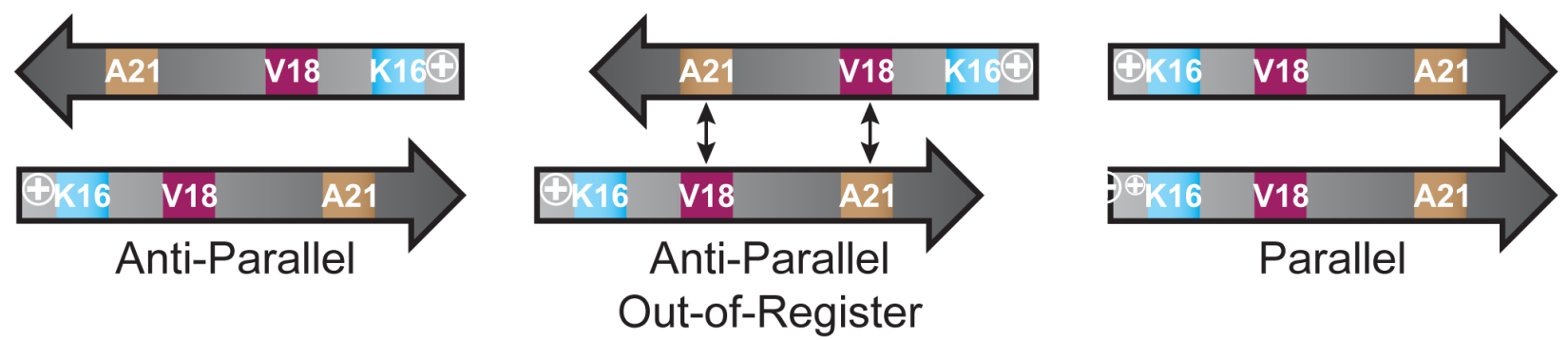

Figure 1. Strand conformations of $A \beta(16-22) E 22 L$ peptide showing positions of charged lysine (blue) residues. Electrostatic repulsion is attenuated in anti-parallel peptide orientation. Out-of-registry strands place the bulky valine packed with the less bulky alanine. Arrows indicate valine (red)-alanine (brown) cross-strand pairing.

Simulation $^{9-14}$ and emperical ${ }^{15-22}$ analyses of $A \beta(16-22)$ assembly are consistent with an initial solvation free energydriven oligomerization to a particle phase. We reasoned secondary structure formation within the less hydrated peptide particle phase $\mathrm{s}^{22-24}$ may explain the observation that $\mathrm{A} \beta(16-22) \mathrm{E} 22 \mathrm{~L}, \mathrm{Ac}^{-16} \mathrm{KLVFFA}^{22} \mathrm{~L}-\mathrm{NH}_{2}$, matures with antiparallel strand orientations. ${ }^{19}$ Electrostatic repulsion between lysine side chains would select against charged $\mathrm{N}$-terminal lysine residue proximity in parallel strands (Fig. 1) during nucleation.

Given that anti-parallel out-of-register alignment in $A \beta(16-22) E 22 L$ is directed by the preference of the bulky valine side chain at position 18 being across (cross-strand pairing) from the less bulky alanine, ${ }^{19,20}$ we hypothesized that uncharged substitutions would stabilize different strand arrangements. Structural ${ }^{25,26}$ and thermodynamic ${ }^{27}$ investigations have identified ordered glutamine side chains in cross-strand stabilization of parallel registries, and the Dutch mutant of $A \beta^{8}$ manifested as the $A \beta(16-22) E 22 Q$ congener which conservatively swaps a side chain - $\mathrm{OH}$ for an $-\mathrm{NH}_{2}$, appeared suitable to change the energy balance. Quite distinct from previous cytosine substitution ${ }^{28}$ or metal ion binding elements which stabilize sheet stacking interactions ${ }^{29}$, the E22Q substitution could stabilize parallel strand registry through cross-strand pairing via amide side-chain $\mathrm{H}$-bonding.

Fig. 2A shows particles and short twisted ribbons that appear in electron micrographs early after AB(16-22)E22Q peptide dissolution and the FT-IR amide-I stretch centered at $1625 \pm 1 \mathrm{~cm}^{-1}$ indicates $\beta$-sheet assembly (Fig. S1). In contrast with the design for glutamine addition, isotope-edited IR analysis with $13 \mathrm{C}=0$ enrichment at the central F19 residue [1${ }^{13} \mathrm{C}$ FF19A $\beta(16-22)$ E22Q where ${ }^{12} \mathrm{C} /{ }^{13} \mathrm{C}$ coupling is most diagnostic of $\beta$-strand registry ${ }^{19,30,31}$, shows a band splitting ${ }^{19,31-34}$ of almost $40 \mathrm{~cm}^{-1}$ and $a^{12} \mathrm{C} /{ }^{13} \mathrm{C}$ band intensity ratio of less than 1 (Fig $2 \mathrm{C}$, black, S2). These assignments are consistent with previously characterized assemblies ${ }^{30,31,33-37}$, and define one-residue out-of-register antiparallel stranded $\beta$-sheets (Fig 1 ). 

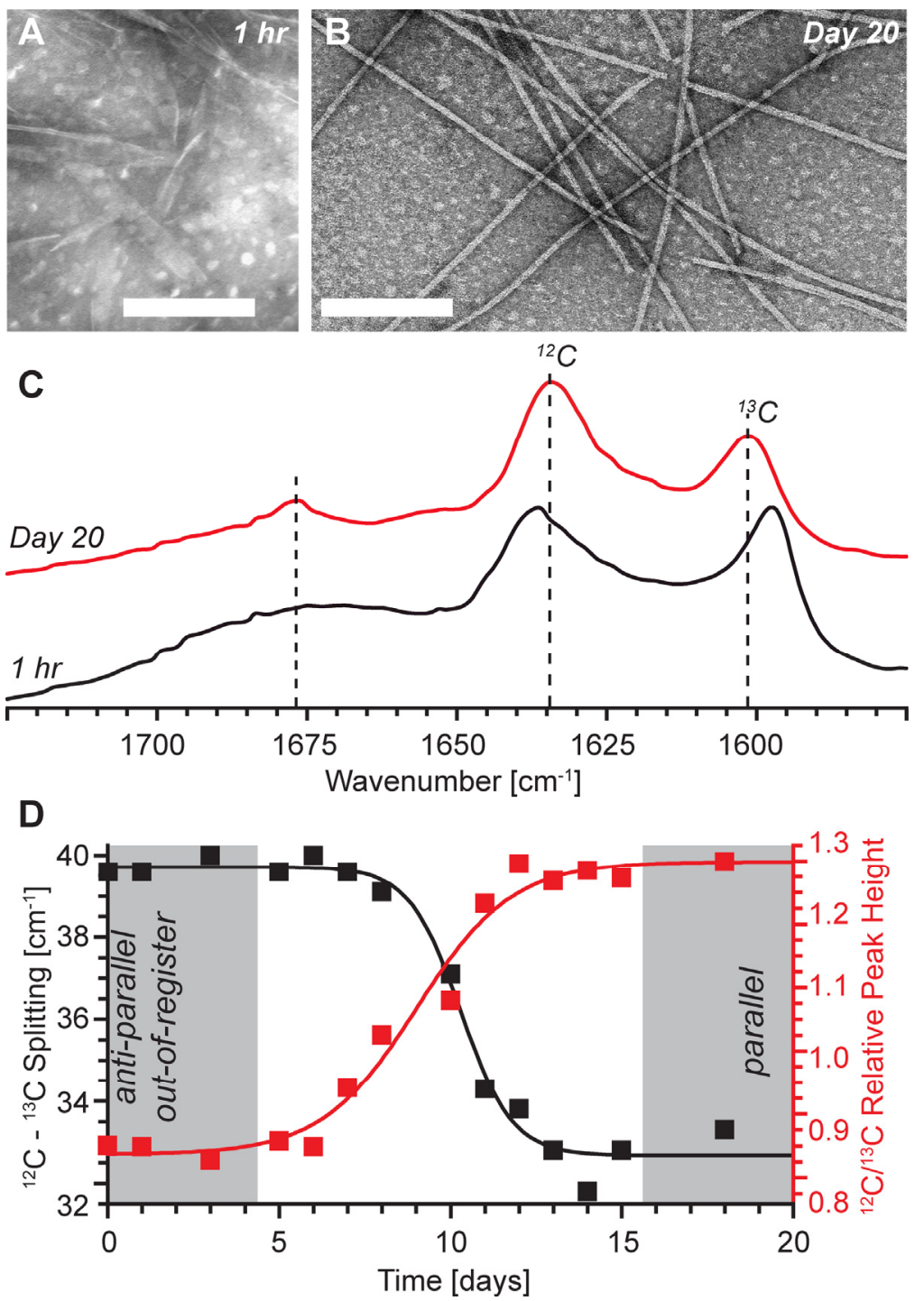

Figure 2. Time dependence of the assembly of $1 \mathrm{mM} \mathrm{A} \beta(16-22) \mathrm{E} 22 \mathrm{Q}$ at acidic $\mathrm{pH}$ in $20 \% \mathrm{CH}_{3} \mathrm{CN}$ containing $0.1 \%$ TFA monitored by $\operatorname{TEM}(\mathrm{A}, \mathrm{B})$ and isotope-edited IR analysis (C,D) using $\left[1-{ }^{13} \mathrm{C}\right] \mathrm{F} 19 \mathrm{~A} \beta(16-22) \mathrm{E} 22 \mathrm{Q}$ assemblies. (A) After 1 hour, wide ribbons (up to 40 $\mathrm{nm}$ ) are observed, in contrast to (B) the $11.6 \pm 1.2 \mathrm{~nm}$ fibers present after 20 days. (C) Dashed lines indicate positions of glutamine side chain, ${ }^{12} \mathrm{C}$ and ${ }^{13} \mathrm{C}$ amide-I band positions in mature fibers. (D) ${ }^{12} \mathrm{C} /{ }^{13} \mathrm{C}$ splitting (black) and relative peak height (red) for assemblies collected at multiples of $24 \mathrm{hr}$ as indicated on the time axis. Scale bars are $200 \mathrm{~nm}$.

However, these assemblies do not persist. Approximately one week after assembly is initiated the FT-IR spectra begins a cooperative transition into long smooth fibers that after 20 days have diameters of $11.6 \pm 1.2 \mathrm{~nm}$ (Fig. 2B,S3). Changes in the frequency and amplitude of the ${ }^{12} \mathrm{C} /{ }^{13} \mathrm{C}$ amide-I bands (Fig. 2D, S4) track with the morphological transitions seen by EM. A CO stretch at $1677 \mathrm{~cm}^{-1}$ assigned to ordered glutamine side chains ${ }^{38,39}$ grew with the transition. The final assemblies with circular dichroism ellipticity minimum at $217 \mathrm{~nm}$ (Fig S5) and X-ray powder diffraction (Fig. S6) d-spacing reflections at 4.76 $\AA$ and $10.1 \AA$ are typical of cross- $\beta$ assemblies. ${ }^{19}$

The orientation and specific registry of each $A \beta(16-22) E 22 Q$ strand is defined via the rate of double-quantum coherence build-up through homonuclear dipolar coupling in ${ }^{13} \mathrm{C}$ DQF-DRAWS ${ }^{40}$ solid-state NMR experiments. Using the infinite array approximation $^{28,41,42}$ (Fig S7), and including the effects of double quantum relaxation ${ }^{41}, T_{2} D Q=11.7 \mathrm{~ms}$ (Fig S8), the build-up of $\left[1-{ }^{13} \mathrm{C}\right]$-L17 intensity from enriched E22Q assemblies uniquely fits a parallel in-register strand arrangement (Fig. 3B, S9). These analyses do not support the glutamine/inter-sheet $\mathrm{H}$-bonding (Q-tracks) prevalent in Huntington's inserts ${ }^{26}$, as they require laminate spacings ${ }^{43}$ of $8 \AA$ for backbone to side chain $\mathrm{H}$-bonding rather than the $10.1 \AA$ spacing seen in these assemblies. These data, together with the glutamine side chain CO stretch at $1677 \mathrm{~cm}^{-1}$ (Fig. 2C, red), are consistent with cross-strand pairing along the sheet surface through extended side chain $\mathrm{H}$-bonding Q-tracks as shown in Fig. $3 \mathrm{C}^{25,26}$ 


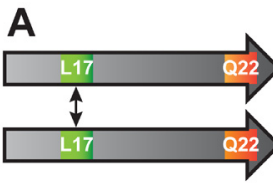

Parallel

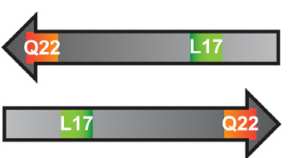

Anti-Parallel

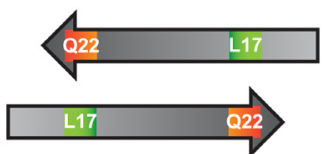

Anti-Parallel Out-of-Register
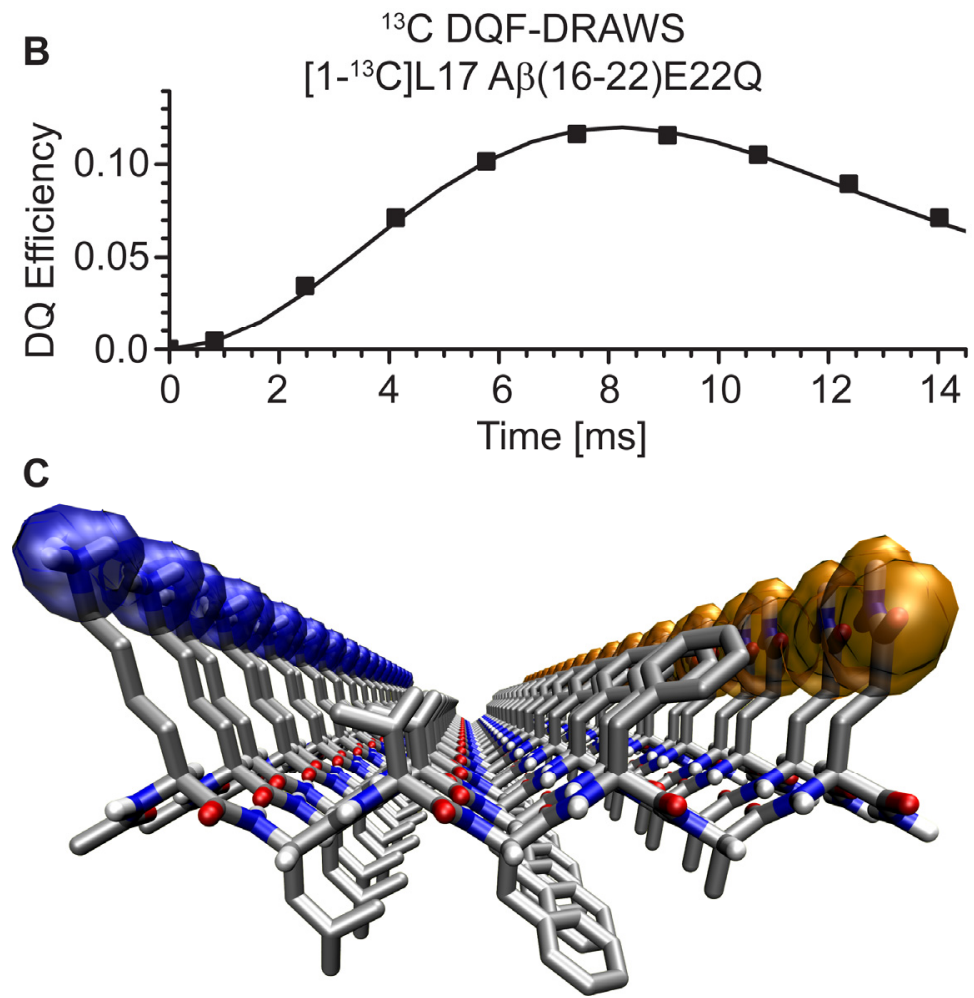

Figure 3. $\beta$-sheet registry in $\mathrm{A} \beta(16-22) \mathrm{E} 22 \mathrm{Q}$ assemblies. (A) Cartoons showing positions of ${ }^{13} \mathrm{C}$ (green) enriched residues in various $\beta$ sheet registries. (B)Determination of peptide registry with ${ }^{13} \mathrm{C}^{-13} \mathrm{C}$ distance measurements between leucine backbone carbonyls of $1 \mathrm{mM}$ [1 $\left.{ }^{13} \mathrm{C}\right] \mathrm{L} 17 \mathrm{~A} \beta(16-22) \mathrm{E} 22 \mathrm{Q}$ assembled as fibers with ${ }^{13} \mathrm{C}$ DQF-DRAWS NMR pulse sequence. Data points are peak intensity for doublequantum buildup divided by total ${ }^{13} \mathrm{C}$ signal intensity. Best fit to DQ buildup (black line) is with a $4.7 \AA^{13} \mathrm{C}^{-13} \mathrm{C}$ distance. $(\mathbf{C}) \mathrm{A} \beta(16-$ 22)E22Q parallel $\beta$-sheet registry. For clarity, non-polar hydrogen atoms are not displayed but the lysine (blue) and glutamine (gold) tracts are highlighted.

$\mathrm{H}$-bond pairing is indirectly evaluated with N5-methylated, $A \beta(16-22) E 22 Q N H C H 3$ and N5,N5-dimethylated, $A \beta(16-$ 22)E22QN $\left(\mathrm{CH}_{3}\right)_{2}$, peptides. The $N^{5}, N^{5}$-dimethyl peptide (Fig. S10C) assemblies, as visualized with EM, appear morphologically indistinguishable from $A \beta(16-22)$ nanotubes and ribbons ${ }^{17,19,22}$. With $\left[1^{-13} \mathrm{C}\right] \mathrm{F} 19$ enrichment, the ${ }^{12} \mathrm{C} /{ }^{13} \mathrm{C}$ band splitting is $40 \mathrm{~cm}^{-1}$ and the diagnostic antiparallel band at $\sim 1695 \mathrm{~cm}^{-1}$ (Table S1 \& Fig S10D) support the same one-residue out-ofregister antiparallel $\beta$-strands. Unlike $A \beta(16-22) E 22 Q$, no distinct IR band at $1677 \mathrm{~cm}^{-1}$ diagnostic for ordered glutamine sidechains is apparent in the $N^{5}, N^{5}$-dimethylated glutamine peptide assemblies. In contrast, the mono-methylated $A \beta(16$ 22) $\mathrm{E} 22 \mathrm{QNHCH} \mathrm{NH}_{3}$ peptide assembles as fibril bundles (Fig S10B) with individual widths ranging from $7 \mathrm{~nm}$ in a single fiber to bundles containing up to five twisted fibers (Fig S11). Time-dependent IR spectra of assembling [1 $\left.1{ }^{13} \mathrm{C}\right] \mathrm{F} 19$ enriched monomethyl peptides (Fig S12) reveals a similar early antiparallel orientation that also transitions to parallel with growth of the glutamine side chain band at $1677 \mathrm{~cm}^{-1}$, but the spectra are most consistent with the mature assemblies containing a mixture of parallel, antiparallel in-register, and antiparallel out-of-register assemblies (Fig S12, inset). Monomethylation appears to weaken the extended glutamine side chain $\mathrm{H}$-bonding Q-track, and is expected to create a methylated surface. We predict that mixed fibers, or even mixed domains within individual fibers, are responsible for the bundling. 


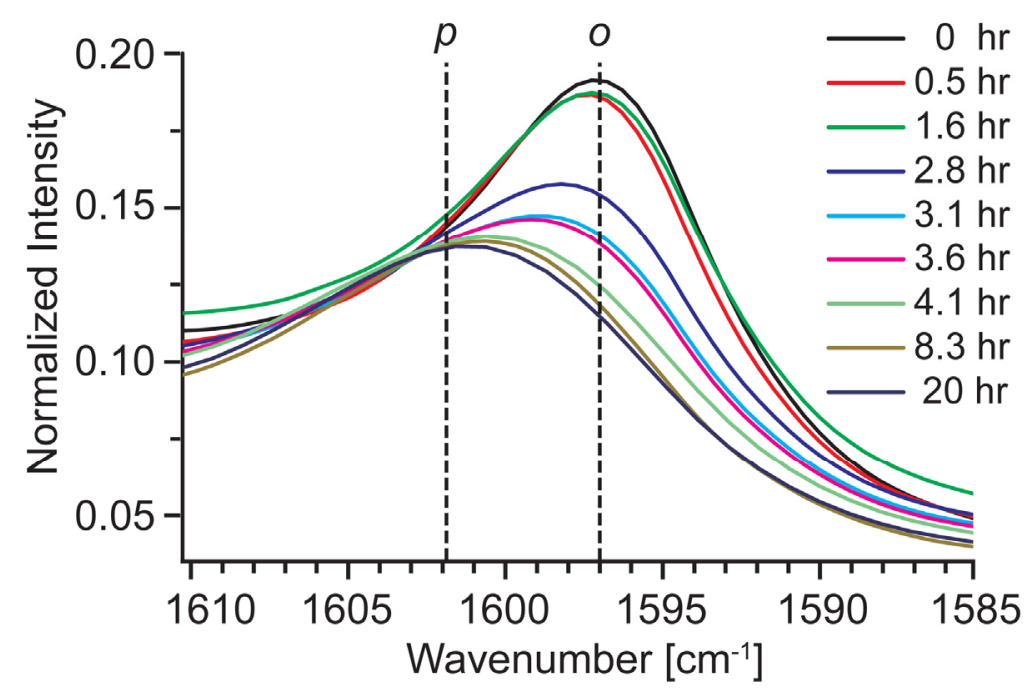

Figure 4. Time dependence of $\mathrm{A} \beta(16-22) \mathrm{E} 22 \mathrm{Q}$ assembly upon seeding with $1 \%$ preformed $\mathrm{A} \beta(16-22) \mathrm{E} 22 \mathrm{Q}$ fibers. FT-IR spectra of ${ }^{13} \mathrm{C}$ amide-I band of $0.8 \mathrm{mM}\left[1^{-13} \mathrm{C}\right] \mathrm{F} 19 \mathrm{~A} \beta(16-22) \mathrm{E} 22 \mathrm{Q}$ seeded with mature $\left[1^{-13} \mathrm{C}\right] \mathrm{F} 19 \mathrm{~A} \beta(16-22) \mathrm{E} 22 \mathrm{Q} .{ }^{13} \mathrm{C}$ band positions for anti-parallel out-of-register (o) and parallel assemblies (p) are indicated with dashed lines.

These data argue that the nucleating core of the $A \beta$ peptide of $A D$ follows an obligatory hydrophobic collapse to intermolecular molten particles. ${ }^{22-24}$ The E22Q substitution provides an energetic constraint sufficient for a new transition, and one that does not manifest in the molten particle phase. The addition of $1 \%$ by weight pre-assembled fibers prepared from mature parallel E22Q assemblies complete the transition to parallel strands within hours (Fig 4, S13). Once initiated, parallel strand assembly propagates quickly, establishing the propagation of parallel strands is not limiting.

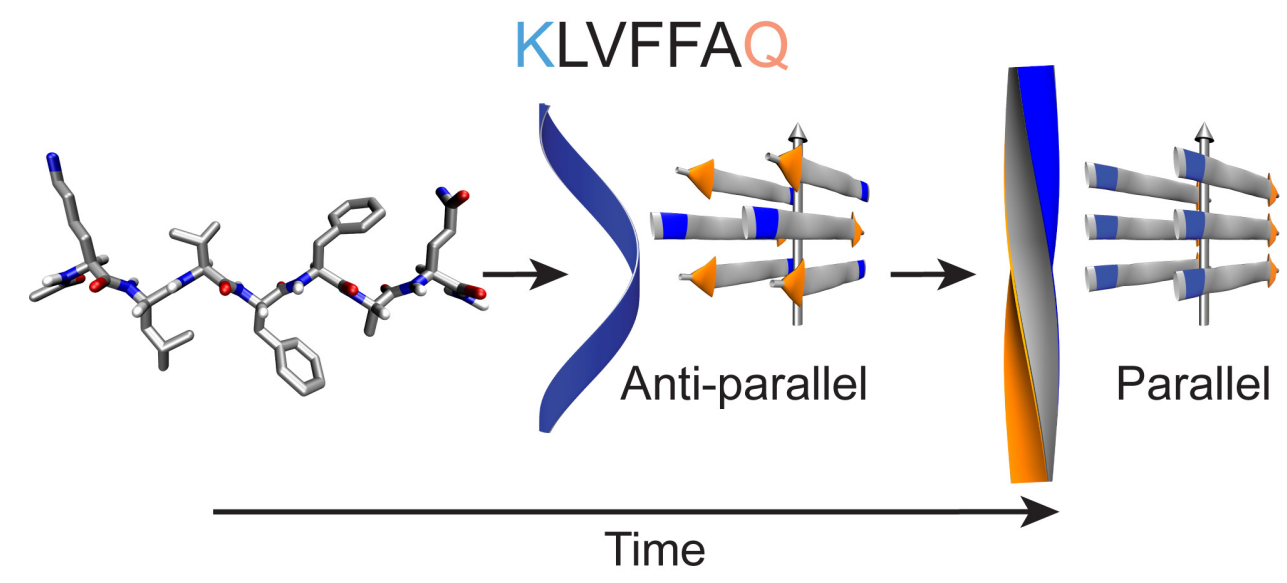

Figure 5. Model for the progressive transitions observed for $A \beta(16-22)$. Paracrystalline forms emerge under these conditions as ribbons with antiparallel out-of-register $\beta$-strands. A subsequent transition to fibers is observed with parallel in-register strands. In cartoons, blue represents lysine residues and orange represents glutamine residues.

Simulations of propagation find that the growing fiber ends can accept strands with altered orientations, ${ }^{13}$ and in the aqueous environment on a template where lysine side-chain repulsion may be attenuated and cross-strand pairing to a pre-organized glutamine side-chain stabilizing (Fig. 3C), conformational "mutations" could accumulate as stabilized by extended glutamine side chain H-bonded Q-tracks. After a certain parallel concentration threshold is reached, fibril fragmentation of mutation-rich domains would generate new parallel ends and grow autocatalytically. This mechanism makes several predictions, which can now be explored through experimentation and simulation. Other mechanistic models, including the glutamine-rich C-termini exposed along the length of the fibril (Fig 5) serving as a secondary nucleation site, ${ }^{4,5}$ need also to be explored.

Like many materials, ${ }^{44}$ these minimal amyloid peptides experience the competing tensions of thermodynamicallycontrolled growth and kinetic nucleation, but amyloid assemblies have also been implicated in disease evolution. ${ }^{2,45-47}$ While the larger disease relevant peptides certainly have greater potential for kinetic and thermodynamic conformational diversity, their assembly is also expected to be even more diversified by the complex fluid ${ }^{48}$ environment of the eukaryotic 
cell. The conformational evolution seen in disease likely follows a progressive and irreversible path, and any of these kinetically accessible phases ${ }^{49}$ could be nucleated and stabilized by the cellular matrix for a Darwinian-like diversification and selection. ${ }^{2,45,50}$ Reconsideration of the confounding determinants required for a conformational evolution in the cell could open new strategies for defining and diverting disease-relevant assemblies for therapeutic intervention.

\section{ASSOCIATED CONTENT}

\section{Supporting Information}

Synthetic and experimental details, including peptide synthesis and purification, synthesis of methylated glutamine, NMR, TEM, CD and XRD. This material is available free of charge via the Internet at http://pubs.acs.org.

\section{AUTHOR INFORMATION}

\section{Corresponding Authors}

anil.mehta@emory.edu; david.lynn@emory.edu

\section{Present Address}

$\dagger$ Department of Developmental Biology, Stanford University School of Medicine, Stanford, CA 94305.

\section{Author Contributions}

$\$$ These authors contributed equally.

\section{Notes}

The authors declare no competing financial interests.

\section{ACKNOWLEDGMENT}

We are indebted to Jeannette Taylor and the Robert P. Apkarian Microscopy Core, Emory University, for TEM training and analyses. The authors acknowledge NSF and NASA astrobiology Program, under the NSF Center for Chemical Evolution CHE¹004560 for development of peptide congeners and by the Division of Chemical Sciences, Geosciences, and Biosciences, Office of Basic Energy Sciences of the U.S. Department of Energy through Grant DE-ER15377 for structural analyses.

\section{REFERENCES}

(1) Eichner, T.; Radford, S. E. Mol. Cell 2011, 43, 8.

(2) Jucker, M.; Walker, L. C. Nature 2013, 501, 45

(3) Kabir, M. E.; Safar, J. G. Prion 2014, 8, 111.

(4) Jeong, J. S.; Ansaloni, A.; Mezzenga, R.; Lashuel, H. A.; Dietler, G. J. Mol. Biol. 2013, 425, 1765

(5) Meisl, G.; Yang, X.; Hellstrand, E.; Frohm, B.; Kirkegaard, J. B.; Cohen, S. I. A.; Dobson, C. M.; Linse, S.; Knowles, T. P. J. Proc. Natl. Acad. Sci. U.S.A. 2014, 111, 9384 .

(6) Wood, S. J.; Wetzel, R.; Martin, J. D.; Hurle, M. R. Biochemistry 1995, 34, 724.

(7) Tjernberg, L. O.; Naslund, J.; Lindqvist, F.; Johansson, J.; Karlstrom, A. R.; Thyberg, J.; Terenius, L.; Nordstedt, C. J Biol Chem 1996, 271, 8545

(8) van Duinen, S. G.; Castaño, E. M.; Prelli, F.; Bots, G. T.; Luyendijk, W.; Frangione, B. Proc. Natl. Acad. Sci. U.S.A. 1987, 84, 5991.

(9) Ma, B.; Nussinov, R. Proc. Natl. Acad. Sci. U.S.A. 2002, 99, 14126.

(10) Klimov, D. K.; Thirumalai, D. Structure 2003, 11, 295.

(11) Santini, S.; Mousseau, N.; Derreumaux, P. J Am Chem Soc 2004, 126, 11509.

(12) Krone, M. G.; Hua, L.; Soto, P.; Zhou, R.; Berne, B. J.; Shea, J. E. J Am Chem Soc 2008, $130,11066$.

(13) Wallace, J. A.; Shen, J. K. Biochemistry 2010, 49, 5290.

(14) Matthes, D.; Gapsys, V.; de Groot, B. L. J Mol Biol 2012, 421, 390

(15) Balbach, J. J.; Ishii, Y.; Antzutkin, O. N.; Leapman, R. D.; Rizzo, N. W.; Dyda, F.; Reed, J.; Tycko, R. Biochemistry $2000,39,13748$.

(16) Petty, S. A.; Decatur, S. M. J Am Chem Soc 2005, 127, 13488.

(17) Lu, K.; Jacob, J.; Thiyagarajan, P.; Conticello, V. P.; Lynn, D. G. J Am Chem Soc 2003, $125,6391$.

(18) Krysmann, M. J.; Castelletto, V.; Hamley, I. W. Soft Matter 2007, 3, 1401.

(19) Mehta, A. K.; Lu, K.; Childers, W. S.; Liang, Y.; Dublin, S. N.; Dong, J.; Snyder, J. P.; Pingali, S. V.; Thiyagarajan, P.; Lynn, D. G. J Am Chem Soc 2008, 130, 9829.

(20) Liang, Y.; Pingali, S. V.; Jogalekar, A. S.; Snyder, J. P.; Thiyagarajan, P.; Lynn, D. G. Biochemistry 2008, $47,10018$.

(21) Senguen, F. T.; Lee, N. R.; Gu, X.; Ryan, D. M.; Doran, T. M.; Anderson, E. A.; Nilsson, B. L. Mol Biosyst 2011, 7, 486.

(22) Childers, W. S.; Anthony, N. R.; Mehta, A. K.; Berland, K. M.; Lynn, D. G. Langmuir 2012, $28,6386$.

(23) Liang, Y.; Lynn, D. G.; Berland, K. M. J Am Chem Soc 2010, 132, 6306.

(24) Anthony, N. R.; Mehta, A. K.; Lynn, D. G.; Berland, K. M. Soft Matter 2014, 10, 4162

(25) Chan, J. C. C.; Oyler, N. A.; Yau, W. M.; Tycko, R. Biochemistry 2005, 44, 10669

(26) Schneider, R.; Schumacher, M. C.; Mueller, H.; Nand, D.; Klaukien, V.; Heise, H.; Riedel, D.; Wolf, G.; Behrmann, E.; Raunser, S.; Seidel, R.; Engelhard, M.; Baldus, M. J Mol Biol 2011, 412, 121.

(27) Bhattacharyya, A. M.; Thakur, A. K.; Wetzel, R. Proc. Natl. Acad. Sci. U.S.A. 2005, 102, 15400

(28) Liu, P.; Ni, R.; Mehta, A. K.; Childers, W. S.; Lakdawala, A.; Pingali, S. V.; Thiyagarajan, P.; Lynn, D. G. J Am Chem Soc $2008,130,16867$.

(29) Dong, J.; Shokes, J. E.; Scott, R. A.; Lynn, D. G. J Am Chem Soc 2006, 128, 3540.

(30) Brauner, J. W.; Dugan, C.; Mendelsohn, R. J Am Chem Soc 2000, 122, 677.

(31) Welch, W. R. W.; Keiderling, T. A.; Kubelka, J. J Phys Chem B 2013, 117, 10359. 
(32) Kubelka, J.; Keiderling, T. A. J Am Chem Soc 2001, 123, 6142.

(33) Decatur, S. M. Acc Chem Res 2006, 39, 169.

(34) Shim, S. H.; Gupta, R.; Ling, Y. L.; Strasfeld, D. B.; Raleigh, D. P.; Zanni, M. T. Proc. Natl. Acad. Sci. U.S.A. 2009, 106,6614

(35) Paul, C.; Axelsen, P. H. J Am Chem Soc 2005, 127, 5754.

(36) Petty, S. A.; Decatur, S. M. Proc. Natl. Acad. Sci. U.S.A. 2005, 102, 14272.

(37) Strasfeld, D. B.; Ling, Y. L.; Gupta, R.; Raleigh, D. P.; Zanni, M. T. J Phys Chem B 2009, 113, 15679.

(38) Barth, A. Prog Biophys Mol Biol 2000, 74, 141.

(39) Jayaraman, M.; Kodali, R.; Sahoo, B.; Thakur, A. K.; Mayasundari, A.; Mishra, R.; Peterson, C. B.; Wetzel, R. J. Mol. Biol. $2012,415,881$.

(40) Gregory, D. M.; Mehta, M. A.; Shiels, J. C.; Drobny, G. P. J. Chem. Phys. 1997, 107, 28.

(41) Gregory, D. M.; Benzinger, T. L.; Burkoth, T. S.; Miller-Auer, H.; Lynn, D. G.; Meredith, S. C.; Botto, R. E. Solid State Nucl Magn Reson 1998, 13,149

(42) Benzinger, T. L. S.; Gregory, D. M.; Burkoth, T. S.; Miller-Auer, H.; Lynn, D. G.; Botto, R. E.; Meredith, S. C. Proc. Natl. Acad. Sci. U.S.A. 1998, 95, 13407.

(43) Sikorski, P.; Atkins, E. Biomacromolecules 2005, 6, 425.

(44) Thanh, N. T. K.; Maclean, N.; Mahiddine, S. Chem. Rev. 2014, 114, 7610.

(45) Li, J.; Browning, S.; Mahal, S. P.; Oelschlegel, A. M.; Weissmann, C. Science 2010, 327, 869.

(46) Goodwin, J. T.; Mehta, A. K.; Lynn, D. G. Acc Chem Res 2012, 45, 2189.

(47) Makarava, N.; Baskakov, I. V. PLoS Pathog. 2013, 9, e1003759.

(48) Fuller, G. G.; Vermant, J. Annu Rev Chem Biomol Eng 2012, 3, 519.

(49) Matsuzaki, K. Acc Chem Res 2014, 47, 2397.

(50) Collinge, J. Science 2010, 328, 1111. 